\title{
A Critical Look at Different Classifications of Curriculum Principles: The Influence on Enhancing Learners' Autonomy
}

\author{
Parviz Maftoon \\ Ph.D., Faculty Member, Department of English \\ Science and Research Branch \\ Islamic Azad University, Tehran, Iran \\ E-mail: pmaftoon@srbiau.ac.ir
}

Saeid Najafi Sarem (Corresponding author)

Ph.D. Student, English department,

Hamadan Branch, Islamic Azad University, Hamedan, Iran

Postal Box: 6541955113, Asadabad, Hamadan, Iran

Tel: 98-9188162035,_E-mail: s_najafisarem@yahoo.com

Received: 13-07- 2012

doi:10.7575/ijalel.v.1n.6p.232
Accepted: 31-08- 2012

Published: 01-11- 2012

URL: http://dx.doi.org/10.7575/ijalel.v.1n.6p.232

\begin{abstract}
In recent decades, following the shift of focus from the previous teacher-centered approaches and the emergence of social constructivist theories, learner autonomy has come to be considered as an important goal in the process of second language teaching and learning. Therefore, in the domain of L2 education, much effort has been made to make learners take on more responsibility for their own learning. In this direction, all attempts have concentrated merely on learners' variables or teachers' own practices neglecting the crucial place of instructional materials as an integral component of curriculum. Instructional materials generally serve as the basis for much of the language input learners receive and the language practice that occurs in the classroom. Therefore, realizing the key role of materials, a lot of research began to focus on devising out certain principles aimed at improving language syllabus or curriculum. Two main trends of research are remarkable in this regard. The first line of research deals with designing principles which are mostly confined to the organization and gradation of content for language course materials. The second line of research focuses on designing principles through which the instructional materials can enhance learner autonomy. Consequently, the present article has been developed in an attempt to first take a general look at some of the main classifications of these principles, and second and most importantly to elaborate in detail on those principles of language curriculum and course design which lead to increased autonomy in the learners. Finally, the implications and applications of such an approach will be discussed for all the stakeholders in the field.
\end{abstract}

Keywords: Curriculum, Curriculum Principles, Learner Autonomy

\section{Introduction}

Second language learning history has undergone a very dynamic path influenced by the dominant paradigms in the field. In every specific point at time, the ruling paradigm has led to a specific theory of language and learning, which in turn has created different teacher and learner roles, different sets of principles and ultimately different syllabi designed based on the underlying premises of each teaching methodology. For a long time, teacher-centered approaches were prevalent in the field and learners were seen as merely the passive imitators of the teacher's model. However, the new trends of research in psychology, sociology and linguistics, opened up new insights on language teaching, learning and the role of learners in the language learning process. As a result, the process syllabus (Breen, 1987), the learner-centered approach (Nunan, 1988), Piaget's cognitive psychology (1977) and Volgosky's social cognition (1979) emerged which all emphasized a learner's central place in the classroom. 
More specifically, as it was mentioned, in the area of syllabus design, the previous product-based structural, lexical, notional, functional, and situational and topical syllabi were replaced by process-based procedural and task syllabuses. The emergent paradigm, as Breen (1987, p. 160) remarks, was concerned with "how" something is done, including how to communicate in the classroom and how to learn how to communicate, and is typified in task-based and process syllabi.

Due to these shifts of focus, teachers began to attach more importance to learners' cognition, personality, motivation as well as the processes involved in language learning. As Nunan (1988) states it is learners who are supposed to play an active role in the learning process and take more responsibility for their own learning. Thus, learner autonomy came to be the aim and focus of attention both in the teaching practices and by those involved in designing language course materials and curriculum development. According to Benson (2001) a course that caters for a variety of competence levels, needs and interests and whose main aim is to foster learner autonomy has to provide for the skills that students need in order to take control of their own learning process.

Thus, a working definition of learner autonomy is needed and the skills involved need to be identified. Taking responsibility for one's own learning is a recurrent notion in works on autonomy (Holec, 1981; Dickinson, 1987; Little 1991; Benson 2001). Specifically, Holec (1981, p. 3) defines autonomy as "the ability to take charge of one's own learning", which involves making decisions about different aspects of the language learning process including determining objectives, monitoring progress, or evaluating performance. Along similar lines, Little (1991, p. 4) views autonomy as "a capacity for detachment, critical reflection, decision-making, and independent action". However, he adds an essential psychological dimension, which entails that "the learner will develop a particular kind of psychological relation to the process and content of his learning".

Taking a look at the available literature on this issue, it is revealed that, so far, most of the research studies and discussions have dealt with the theoretical background of learner autonomy, and the role played by learner variables such as attitudes, beliefs, strategies, and roles. It is considerably less common to read reports of the role of language curriculum, syllabus and more specifically our classroom-based courses which integrate principles of learner autonomy in their design. Considering the main variables involved in language learning, that is, the teacher, the learners, and the input, the role of instructional materials serving as the input receives higher importance, so that, much scrutiny should be utilized in the process of curriculum development and syllabus design. As Richards (2001, p. 252) maintains teaching materials are a key component in most language programs. Instructional materials generally serve as the basis for much of the language input learners receive and the language practice that occurs in the classroom. In the case of inexperienced teachers, materials may also serve as a form of teacher training - they provide ideas on how to plan and teach lessons as well as formats that teachers can use. (Richards, 2001, p. 252)

Taking the above points into account concerning the key place of materials as sources of input, a variety of principles and guidelines has been proposed by different scholars aimed at helping the curriculum developers and syllabus designers in organizing instructional materials as well as language courses. Among these sets of principles we can refer to Brown (1993), Ellis (2005), Hansen (1995), Hall (1995), Johnson (1989), Krahnke and Christison (1983), and most recently, Nation and Macalister (2010), and Tomlinson (2010). All these scholars have mostly focused on a set of characteristics and principles that should be considered in developing materials in the process of language teaching and learning. In other words it can be claimed that these principles relate mainly to the organization of the content of instructional materials in which there are many overlapping areas. Considering these points, the present article is of two-fold. First, it will take a quick look at some of the important classifications of principles proposed by the above-mentioned scholars. Second and most importantly which is the focus of the current paper, the classification of Cotterall (2000) which has direct impact on learner autonomy will be discussed in detail.

\section{Classifications of Curriculum Principles}

\subsection{Nation and Macalister (2010) Classification of Principles}

According to Nation and Macalister (2010), principles provide a sensible basis to guide teaching and to help in the design of courses. Principles must be based on research and theory, and must be general enough to allow variety and flexibility in their application to suit the wide range of conditions in which language is taught. Principles may be based on a pedagogical perspective, focusing on curriculum design and teacher training; on a learning perspective; or on a philosophical stance considering the nature of language, the nature of learning and the role of culture. Nation and Macalister (2010) have proposed a set of twenty principles which are supported by research and theory in any of three fields: second or foreign language learning, first language learning, and 
International Journal of Applied Linguistics \& English Literature

ISSN 2200-3592 (Print), ISSN 2200-3452 (Online)

Vol. 1 No. 6; November 2012

general educational research and theory. None of the principles is unique to language teaching, but could equally well apply to the teaching of mathematics or motorcycle maintenance. Their application, however, must draw as much as possible on research and theory within their field of application.

Nation and Macalister (2010) divide the principles of language curriculum development into three groups. The first group of principles deals with content and sequencing. They are concerned with what goes into a language course and the order in which language items appear in the course. The aim of these principles is to make sure that the learners are gaining something useful from the course. It is possible to run a language course which is full of interesting activities and which introduces the learners to new language items, but which provides a very poor return for the time invested in it. This poor return can occur because many of the lessons do not contain anything new to learn, because the new items have very little value in the ordinary use of the language, or because they set out interference conditions which result in a step backwards in learning rather than a step forwards.

The second group of principles deals with format and presentation. They are concerned with what actually happens in the classroom during the learning. Most practically, they relate to the kinds of activities used in the course and the ways in which learners process the course material. It is in this aspect of curriculum design that teachers may have their greatest influence on the course. (Nation \& Macalister, 2010, pp. 39-40)

The third group of principles deals with monitoring and assessment and to some degree evaluation. In each of these groups, the principles have been ranked in order of their importance, so that the first principle in the group is the most important of that group, the second principle is the next most important and so on. (Nation \& Macalister, 2010, p. 40). The detailed set of principles proposed by Nation and Macalister (2010) is presented in table 1. Below:

Table 1. Twenty principles of language teaching

\begin{tabular}{|c|c|}
\hline $\mathbf{A}$ & Content and Sequencing \\
\hline 1. Frequency & $\begin{array}{l}\text { A language course should provide the best possible coverage of language in use through } \\
\text { the inclusion of items that occur frequently in the language, so that learners get the best } \\
\text { return for their learning effort. }\end{array}$ \\
\hline $\begin{array}{l}\text { 2. Strategies and } \\
\text { autonomy }\end{array}$ & $\begin{array}{l}\text { A language course should train learners in how to learn a language and how to monitor } \\
\text { and be aware of their learning, so that they can become effective and independent } \\
\text { language learners. }\end{array}$ \\
\hline $\begin{array}{l}\text { 3. Spaced } \\
\text { retrieval }\end{array}$ & $\begin{array}{l}\text { Learners should have increasingly spaced, repeated opportunities to retrieve and give } \\
\text { attention to wanted items in a variety of contexts. }\end{array}$ \\
\hline $\begin{array}{l}\text { 4. Language } \\
\text { system }\end{array}$ & The language focus of a course needs to be on the generalizable features of the language. \\
\hline $\begin{array}{l}\text { 5. Keep moving } \\
\text { forward }\end{array}$ & A language course should progressively cover useful language items, skills and strategies. \\
\hline 6. Teachability & $\begin{array}{l}\text { The teaching of language items should take account of the most favorable sequencing of } \\
\text { these items and should take account of when the learners are most ready to learn them. }\end{array}$ \\
\hline $\begin{array}{l}\text { 7. Learning } \\
\text { burden }\end{array}$ & The course should help learners make the most effective use of previous knowledge. \\
\hline 8. Interference & $\begin{array}{l}\text { The items in a language course should be sequenced so that items which are learned } \\
\text { together have a positive effect on each other for learning and so that interference effects } \\
\text { are avoided. }\end{array}$ \\
\hline B & Format and Presentation \\
\hline 1. Motivation & $\begin{array}{l}\text { As much as possible, the learners should be interested and excited about learning the } \\
\text { language and they should come to value this learning. }\end{array}$ \\
\hline 2. Four strands & $\begin{array}{l}\text { A course should include a roughly even balance of meaning-focused input, } \\
\text { language-focused learning, meaning-focused output and fluency activities. }\end{array}$ \\
\hline
\end{tabular}


International Journal of Applied Linguistics \& English Literature

ISSN 2200-3592 (Print), ISSN 2200-3452 (Online)

Vol. 1 No. 6; November 2012

\begin{tabular}{|c|c|}
\hline $\begin{array}{l}\text { 3.Comprehensible } \\
\text { input }\end{array}$ & $\begin{array}{l}\text { There should be substantial quantities of interesting comprehensible receptive activity in } \\
\text { both listening and reading. }\end{array}$ \\
\hline 4. Fluency & $\begin{array}{l}\text { A language course should provide activities aimed at increasing the fluency with which } \\
\text { learners can use the language they already know, both receptively and productively. }\end{array}$ \\
\hline 5. Output & $\begin{array}{l}\text { The learners should be pushed to produce the language in both speaking and writing over } \\
\text { a range of discourse types. }\end{array}$ \\
\hline $\begin{array}{l}\text { 6. Deliberate } \\
\text { learning }\end{array}$ & $\begin{array}{l}\text { The course should include language-focused learning on the sound system, spelling, } \\
\text { vocabulary, grammar and discourse areas. }\end{array}$ \\
\hline 7. Time on task & As much time as possible should be spent using and focusing on the second language. \\
\hline $\begin{array}{l}\text { 8. Depth of } \\
\text { processing }\end{array}$ & Learners should process the items to be learned as deeply and as thoughtfully as possible \\
\hline $\begin{array}{l}\text { 9. Integrative } \\
\text { motivation }\end{array}$ & $\begin{array}{l}\text { A course should be presented so that the learners have the most favourable attitudes to the } \\
\text { language, to users of the language, to the teacher's skill in teaching the language, and to } \\
\text { their chance of success in learning the language. }\end{array}$ \\
\hline 10 Learning style & $\begin{array}{l}\text { There should be opportunity for learners to work with the learning material in ways that } \\
\text { most suit their individual learning style. }\end{array}$ \\
\hline $\mathbf{C}$ & Monitoring and Assessment \\
\hline $\begin{array}{l}1 \text { Ongoing needs } \\
\text { and environment } \\
\text { analysis: }\end{array}$ & $\begin{array}{l}\text { The selection, ordering, presentation, and assessment of the material in a language course } \\
\text { should be based on a continuing careful consideration of the learners and their needs, the } \\
\text { teaching conditions, and the time and resources available. }\end{array}$ \\
\hline 2 Feedback: & $\begin{array}{l}\text { Learners should receive helpful feedback which will allow them to improve the quality of } \\
\text { their language use. }\end{array}$ \\
\hline
\end{tabular}

\subsection{Johnson's (1989) Basic Principles of Language Curriculum Design}

Another important set of principles of language curriculum design is proposed by Johnson (1989). This classification consists of three principles including coherence, permanent change and innovation, and different approaches integration, each of which is explained briefly below.

\subsubsection{Coherence}

A curriculum is considered to be coherent when learners' achievements correspond to the curriculum aim and when there is logical relationship between the objectives stated and the process planned and developed in the classroom.

An example of incoherent curriculum may be when communicative language teaching is designed within the framework of a language-centered curriculum.

\subsubsection{Permanent change and innovation}

It is impossible to design a curriculum once forever; no curriculum can be perfect and it will always need some improvements, adjustments or "fine tuning" to meet the learners needs in the best possible way. But it is necessary to keep in mind that the change of one of the curriculum components will inevitably provoke change in the other components.

\subsubsection{Different approaches integration}

The idea of product (skills-based) and process (procedures or task-based) approaches integration is of great importance for language programme design. This principle is connected with the principle of coherence too, because the logical relationship between the objectives identified and the process developed in the classroom is presented through the integration of skills-based and procedural curriculum.

\subsection{Tomlinson's (2010) Classification of Principles}

Tomlinson (2010) offers some principles of language acquisition that should be taken into account while developing materials. These principles are as follows: 
International Journal of Applied Linguistics \& English Literature

ISSN 2200-3592 (Print), ISSN 2200-3452 (Online)

Vol. 1 No. 6; November 2012

1. A prerequisite for language acquisition is that the learners are exposed to a rich, meaningful, and comprehensible input of language in use.

2. In order for the learners to maximize their exposure to language in use, they need to be engaged both affectively and cognitively in the language experience.

3. Language learners who achieve positive affect are much more likely to achieve communicative competence than those who do not.

4. L2 language learners can benefit from using those mental resources that they typically utilize when acquiring and using their L1.

5. Language learners can benefit from noticing salient features of the input.

6. Learners need opportunities to use language to try to achieve communicative purposes.

Likewise, Tomlinson (2010) develops some principles of language teaching that should be taken into account while developing language. These principles are as follows:

1. The content and methodology of the teaching should be consistent with the objectives of the course and should meet the needs and wants of the learners.

2. The teaching should be designed to help learners to achieve language development and not just language acquisition.

3. The teaching should be designed so as to provide the learners with learning opportunities that will help them to develop educationally in the sense that they become more mature, more critically astute, more creative, more constructive, more collaborative, more capable and more confident as a result of the course.

4. The teachers needs to be able to personalize and localize the materials and to relate them in different ways to the needs, wants, and learning style preferences of individual learners.

Tomlinson (2010) also refers to Hall's (1995) principles and introduces the following as the main guidelines in Hall's view which underpin everything we do in planning and writing our materials:

- $\quad$ the need to communicate

- the need for long-term goals

- the need for authenticity

- the need for student-centeredness

Reviewing some of the main classifications of principles proposed by Nation and Macalister (2010), Johnson (1989), Tomlinson (2010), and finally Hall (1995), one can understand that there are many overlapping principles across these models. The common goal they follow is that they all concentrate on presenting a group of guidelines and features which have to be taken into account both by teachers and material developers in the organization and gradation of the materials to be included in the course design. They seldom focus on the actual effects these principles may bear both the learners and the processes involved in the learning. However, the principles proposed by Cotterall (2000) seems to be more useful in that he just concentrated on those features of the instructional materials and course design which are more contributing in enhancing the autonomy of the learners which seem to be the ultimate goal of the language teaching and learning enterprise. Next section is devoted to a critical look at the principles proposed by Cotterall (2000) and its effect on improving the learners' autonomy.

\subsection{Cotterall's (2000) Classification of Principles and Learner Autonomy}

As was mentioned earlier in this paper, following the constructivist school of thought and the learner-centered approaches in language teaching, the term learner autonomy came to be noticed and given preference in language pedagogy. The term learner autonomy was first coined in 1981 by Henri Holec, who is considered as the "father" of learner autonomy. Autonomy is seen either as a means or as an end in education and based on its originator Holec (1981, p. 3) is defined "the ability to take charge of one's learning". The term autonomy, according to Benson and Voller (1997, p. 2): has come to be used in at least five ways:

- for situations in which learners study entirely on their own;

- for a set of skills which can be learned and applied in self-directed learning; 
- for an inborn capacity which is suppressed by institutional education;

- for the exercise of learners' responsibility for their own learning;

- for the right of learners to determine the direction of their own learning.

As Little (1991, p. 4) remarks the shift of responsibility from teachers to learners does not exist in a vacuum, but is the result of a concatenation of changes to the curriculum itself towards a more learner-centered kind of learning. Candy (1991) says that learner autonomy does not mean that the teacher becomes redundant, abdicating his/her control over what is transpiring in the language learning process. Learner autonomy is a perennial dynamic process amenable to 'educational interventions' rather than a static product, a state, which is reached once and for all (Candy, 1991). Therefore, instead of just considering autonomy as a characteristic influenced by individual variables like learning habits, learning styles, interests, attitudes, strategies and motivation, many language teachers are convinced of the importance of incorporating principles of learner autonomy into their practice and most importantly in their design of language courses.

Cotterall (2000) argues that learner autonomy should not be seen as a goal only for highly committed students completing optional courses, or for students operating within selected educational or cultural contexts. Rather, it should be seen as an essential goal of all learning. Littlewood (1999, p. 73) comments:

If we define autonomy in educational terms as involving students' capacity to use their learning independently of teachers, then autonomy would appear to be an incontrovertible goal for learners everywhere, since it is obvious that no students, anywhere, will have their teachers to accompany them throughout life.

According to Cotterall (2000) language courses which aim to promote learner autonomy will incorporate means of transferring responsibility for aspects of the language learning process (such as setting goals, selecting learning strategies, and evaluating progress) from the teacher to the learner. Cotterall (2000) proposed the following five general principles of language course design:

1. learner goals,

2. the language learning process,

3. tasks,

4. learner strategies, and

5. reflection on learning.

According to Holec (1981, p. 3) the challenge facing course designers who wish to foster learners' ability to 'take charge of their learning' is to find ways of supporting the transfer of responsibility for decision-making about learning from teacher to learner. As was mentioned above, each of the principles proposed here by Cotterall (2000) contributes to that transfer of responsibility. The first principle was mentioned to be setting learner goals. According to Cotterall (2000) the course reflects learners' goals in its language, tasks, and strategies. Any course designed to promote learner autonomy must set out to achieve the goals which the learners deem important. Breen and Candlin (1980, p. 95) comment:

However vague a learner's initial interpretation [of the demands of the target repertoire and its underlying competence] may be, he is not going to learn anything unless he has an idea of what he is trying to achieve.

Therefore, in a course which seeks to foster language learners' autonomy, time is devoted to raising learners' awareness of ways of identifying goals, specifying objectives, identifying resources and strategies needed to achieve goals, and measuring progress. Decisions about language, texts, tasks, and strategies to focus on during the course are made in relation to the stated goals of the learners. (Cotterall, 2000, p. 111)

Cotterall (2000) states that course tasks are explicitly linked to a simplified model of the language learning process. A basic understanding of the language learning process is essential for anyone who wishes to manage their own learning. Learners can only be autonomous if they are aware of a range of learning options, and understand the consequences of choices they make. Armed with a model of language learning, learners are able to question the role of input texts and tasks, to trial alternative strategies, and to seek feedback on their performance. Without access to such a model, learners are forced into the role of 'consumers' of language courses.

Course tasks either replicate real-world communicative tasks or provide rehearsal for such tasks. This principle is related to the first one. Learners enrol in language courses in order to improve their performance of certain L2 
tasks. Their goals and needs must therefore be paramount in the design of any course which seeks to develop their ability to manage their own learning. This means that the tasks in which the course provides preparation, practice, and feedback should be those in which the learner will participate in the future. Such 'transparency' of course content is the hallmark of courses designed to foster learner autonomy.

The course, based on Cotterall (2000), incorporates discussion and practice with strategies known to facilitate task performance. The recent explosion of interest in learning strategies has provided language teachers with suggestions as to which learning strategies to present and, more importantly, empirical justification for spending time with learners discussing and experimenting with such strategies. At the heart of learner autonomy lies the concept of choice. This principle relates particularly to extending the choice of strategic behaviours available to learners, and to expanding their conceptual understanding of the contribution which strategies can make to their learning.

The fifth principle, according to Cotterall (2000), was mentioned to be reflection on learning. The course promotes reflection on learning. In a recent report, Dam and Legenhausen (1999, p. 90) claim that learners' ability to reflect critically on their learning is a measure of the effectiveness of the learning environment. They use the term 'evaluation' to refer to the metacognitive activity of reviewing past and future learning experiences in order to enhance learning, and claim that:

In an autonomous classroom ... [evaluation] is viewed as the pivot of a good learning/teaching cycle ... Evaluation has a retrospective and prospective function, in which the learning experiences of the past are reflected upon and transformed into plans for future action.

The potential for learner autonomy increases as an individual's learning awareness grows. Therefore activities which prompt learners to reflect on their learning aim to enhance learners' insight into their learning processes.

\section{Concluding Remarks}

As was discussed through this literature, a variety of principles has been put forward by different scholars, which are applied in the process of curriculum and syllabus design. As Nation and Macalister (2010) states the importance of all this research is that it provides a theoretical, logical and testable basis for syllabus construction, and that it indicates an effective, though restricted, role for teaching and can lead to teacher development too.

Taking all the principles presented here into consideration, it deserves mentioning that the list of principles, based on Nation and Macalister (2010, p. 66) has a much wider range of uses.

1. It can be used to guide the design of language teaching courses and lessons.

2. It can be used to evaluate existing courses and lessons.

3. It can be used to help teachers integrate and contextualize information gained from keeping up with developments in their field.

4. It can provide a basis for teachers to use to reflect on their practice and professional development. It may provide a basis for action research within their classrooms. It can help them answer questions like "Is this a good technique?", "Should I use group work?", and "Do my learners need to speak a lot in class?".

5. It can act as one of many possible reference points in teacher training courses.

One of the values in using a principle-based approach to language teaching is that developments in theory and research can be easily accommodated by altering, expanding, removing or adding a principle without having to discard all the other principles. In this way our knowledge of language teaching can grow without being subject to the blanket acceptance or rejection that is typical of methods. The information gathered by considering principles, by doing needs analysis, and by doing environment analysis provides essential input for setting course goals and deciding what goes into a course.

From another perspective which was the main focus of the preset article is the positive role which course design principles can play in enhancing the learners' autonomy. Teachers should shift their focus from learner variables to designing instructional materials in a way that make the students take on more responsibility for their own learning. Contrary to other sets of principles, Cotterall's (2000) classification of five principles, which was discussed in detail here, can in fact foster learner autonomy. As a main principle, teachers or material developers should design instructional materials in such a way fostering reflection on learning in students. Without 
International Journal of Applied Linguistics \& English Literature

ISSN 2200-3592 (Print), ISSN 2200-3452 (Online)

Vol. 1 No. 6; November 2012

reflection, learners cannot assess their past learning or plans for future action. Therefore courses designed to promote learner autonomy must encourage learners to set personal goals, monitor and reflect on their performance, and modify their learning behaviour accordingly. To name some of the helpful activities in such an environment, the course design can integrate goal-setting activities, discussion of the language learning process, modeling of strategies, task practice, and reflection on experience. The inclusion of tasks related to learners' goals will result in an unprecedented level of motivation. Furthermore, incorporation of materials on the language learning process (Principle 2) provides the learners with a model for solving their own learning problems and the inclusion of materials on learner strategies (Principle 4) proves an efficient solution to the problem of limited time and can speed up the rate of learning. (Cotterall, 2000)

Cotterall and Crabbe (1999, p. 141) maintain that the essential characteristic of instructional programmes which foster learner autonomy is the way in which they scaffold instruction to provide guidance without assuming control of learners' decision-making: In order to improve individual performance, whether it is teaching or learning, we need a sense of ownership, and power, driven by an exploratory attitude and working within a curricular framework that is flexible and dynamic enough to allow for individual explorations (Cotterall \& Crabbe 1999, p. 141).

Taking into account all the above aspects of curriculum theory, it is possible to come to a conclusion that its application to our teaching practice would result in increased learner autonomy, further teacher development and in the improvement of the whole ELT process.

\section{References}

Benson, P. \& Voller, P. (1997). Autonomy and independence in language Learning. London: Longman. Benson, P. (2001). Teaching and researching autonomy in language learning. Harlow, Essex: Longman.

Breen, M. (1987). Contemporary paradigms in syllabus design. Language Teaching, 20 (2), 81-92. doi:10.1017/S0261444800004365.

Candy (1991). Self-direction for lifelong learning. California: Jossey-Bass.

Cotterall, S. (2000). Promoting learner autonomy through the curriculum: Principles for designing language courses. ELT Journal, 2(54), 109-117.

Cotterall, S. \& Crabbe, D. (1999). Learner autonomy in language learning: Defining the field and effecting change. Frankfurt: Peter Lang.

Dam, L. \& Legenhausen, L. (1999). Language acquisition in an autonomous learning environment: Learners' self-evaluations and external assessments compared. In S. Cotterall and D. Crabbe (eds.), Learner autonomy in language learning: Defining the field and effecting change. Frankfurt: Peter Lang.

Dickinson, L. (1987). Self-instruction in language learning. Cambridge: Cambridge University Press.

Holec, H. (1981). Autonomy in foreign language learning. Oxford: OUP.

Johnson R. K. (1989). The Second language curriculum. Cambridge: Cambridge University Press.

Little, D. (1991). Learner autonomy. 1: Definitions, issues and problems. Dublin: Authentik.

Littlewood, W. (1999). Defining and developing autonomy in East Asian contexts. Applied Linguistics, 20(1), 71-94. doi:10.1093/applin/20.1.71.

Nation, I. S. P., \& Macalister, J. (2010). Language curriculum design. NY: Routledge.

Nunan, D. (1988). The learner-centered curriculum. Cambridge, UK: Cambridge University Press.

Richards, J. C. (2001). Curriculum development in language teaching. NY: CUP.

Tomlinson, B. (2010). Principles of effective materials development. In N. Harwood (ed.), English language teaching materials (pp. 81-108). NY: CUP. 